\title{
Production of Alkaline Protease by Solvent-Tolerant Alkaliphilic Bacillus circulans MTCC 7942 Isolated from Hydrocarbon Contaminated Habitat: Process Parameters Optimization
}

\author{
Ulhas Patil $^{1}$ and Ambalal Chaudhari ${ }^{2}$ \\ ${ }^{1}$ Department of Microbiology, R. C. Patel Arts, Commerce and Science College, Shirpur 425 405, India \\ ${ }^{2}$ School of Life Sciences, North Maharashtra University, Jalgaon 425 001, India \\ Correspondence should be addressed to Ulhas Patil; ulhaskpatil@gmail.com
}

Received 19 September 2013; Accepted 7 October 2013

Academic Editors: B. Penke and W. Sattler

Copyright (C) 2013 U. Patil and A. Chaudhari. This is an open access article distributed under the Creative Commons Attribution License, which permits unrestricted use, distribution, and reproduction in any medium, provided the original work is properly cited.

In the present investigation, a newly isolated organic solvent-tolerant and alkaliphilic bacterial strain was reported from a hydrocarbon (gasoline and diesel) contaminated soil collected from the petrol station, Shirpur (India). The strain was identified as Bacillus circulans MTCC 7942, based on phenotype, biochemical, and phylogenetic analysis of 16S rRNA gene sequence. The capability of Bacillus circulans to secrete an extracellular, thermostable, alkaline protease and grow in the presence of organic solvents was explored. Bacillus circulans produced maximum alkaline protease $(412 \mathrm{U} / \mathrm{mL})$ in optimized medium $(\mathrm{g} / \mathrm{L})$ : soybean meal, 15; starch, 10; $\mathrm{KH}_{2} \mathrm{PO}_{4}, 1 ; \mathrm{MgSO}_{4} \cdot 7 \mathrm{H}_{2} \mathrm{O}, 0.05 ; \mathrm{CaCl}_{2}, 1 ; \mathrm{Na}_{2} \mathrm{CO}_{3}, 8 ; \mathrm{pH} 10.0$ at $37^{\circ} \mathrm{C}$ and $100 \mathrm{rpm}$. The competence of strain to grow in various organic solvents- $n$-octane, dodecane, $n$-decane, N,N-dimethylformamide, $n$-hexane, and dimethyl sulfoxide, establishes its potential as solvent-stable protease source for the possible applications in nonaqueous reactions and fine chemical synthesis.

\section{Introduction}

The world enzyme market will grow up to $\$ 2.1$ billion by 2016 [1]. Of these, alkaline protease alone accounts for $40 \%$ of the total world enzyme production, with growing applications in bakery, brewing, detergent, diagnostic reagents, feeds modification, leather finishing, laundry additives, pharmaceuticals, peptide synthesis, silk, silver recovery from Xray/photographic film, soy processing, and waste treatment [2].

Majority of alkaline proteases produced by mesophilic microbes are effective in a narrow range of $\mathrm{pH}$, temperature, and ionic strength, accordingly unsuitable for commercial purpose under demanding industrial conditions. Hence, alkaline proteases secreted by alkaliphilic bacteria are of potential interest in detergent industry due to their ability to withstand extremes of temperature $\left(40-60^{\circ} \mathrm{C}\right)$, alkaline $\mathrm{pH}$ (9-11), high salt concentration, and other harsh conditions [3].
Alkaline protease that catalyses peptide bond formation in the nonaqueous media has greatly expanded potentials in green chemistry for fine chemical synthesis [4]. Alkaline proteases have expanded new possibilities such as (i) shifting of thermodynamic reaction equilibrium to favour synthesis, (ii) enhancement of bioavailability of hydrophobic substrates, (iii) total inhibition of water-dependent side reactions, (iv) alteration in enantioselectivity of reaction, (v) improving thermal stability, and (vi) facilitating the product recovery. Thus, the stability of proteases in organic solvents offers certain merits like (i) synthesis of various compounds, (ii) bioremediation of waste containing organic solvents, and (iii) possibility of newer reactions like transesterification, ammonolysis, and thiolysis. Hence, the search for alkaline proteases stable to harsh conditions is of great significance. This constitutes the main objective of the present study.

Microbial diversity of exotic environment including manmade biotopes offers an unconditional source to screen versatile microbes with inherent stable proteases. The naturally 
robust protease capable of functioning in harsh conditions is anytime suitable than artificially stabilized enzyme for a biocatalysis in the industry.

Microbe develops an array of physiological and molecular adaptations for survival in virtually every extreme environment. Although, the stability of alkaline protease in the presence of organic solvents has been improved by approaches like physical, chemical modification, immobilization, protein engineering, and recombinant DNA, the selection of microbes secreting alkaline proteases naturally endowed with stability and activity in nonaqueous media from natural or man-made extreme environment can serve the purpose of industry $[5,6]$. In this regard, several solvent-tolerant alkaline protease producers, mainly Bacillus sp. and Pseudomonas sp., from extreme natural habitats have been reported [7-11].

In view of the above facts, the present work describes isolation of a new organic solvent-temperature-tolerant strain of Bacillus circulans from man-made contaminated habitat with emphasis on the optimization of physical and nutritional requirements for the effective production of organic solventstable and extracellular alkaline protease.

\section{Materials and Methods}

2.1. Microorganism. The newly isolated strain (UB2) was identified on the basis of a battery of morphological and biochemical characteristics. The preliminary identification was confirmed by (i) Microbial Type Culture Collection (MTCC), Chandigarh using Biolog microbial identification system (Biolog automated Microstation system, USA), and (ii) taxonomic characterization using nucleotide sequence of 16S rRNA gene as per Sambrook et al. [12]. The strain was maintained on nutrient agar slants at $4^{\circ} \mathrm{C}$.

2.2. Effect of Organic Solvents on Isolated Strain. The organic solvent tolerance of Bacillus circulans MTCC 7942 was analysed as per Ogino et al. [13]. The organic solvent toler- ance against chloroform, acetone, butanol, xylene, benzene, toluene, $n$-octane, dodecane, $n$-decane, N,N-dimethylformamide, cyclohexane $n$-hexane, and dimethyl sulfoxide was confirmed by procedure as described previously [10]. The strain was also cultivated in the absence of organic solvent in an Erlenmeyer flask with a rubber stopper as positive control.

2.3. Protease Assay. Alkaline protease activity, using buffered casein as a substrate was assayed as per Nakanishi et al. [14] with several modifications as described earlier [10]. One unit of alkaline protease activity (U) was defined as that amount of enzyme required to produce peptides equivalent to $1.0 \mu \mathrm{g}$ of tyrosine in the filtrate per minute per $\mathrm{mL}$ at $\mathrm{pH} 10.0$ and $60^{\circ} \mathrm{C}$.

2.4. Protein Determination. The culture free broth was precipitated with $6 \mathrm{~N}$ trichloroacetic acid. The suitably diluted protein aliquot was used for determination of protein concentration at $750 \mathrm{~nm}$ as per Lowry et al. [15] using bovine serum albumin (BSA) as a standard.
2.5. Optimization of Production Medium Ingredients for Protease Production. Various carbon sources (glucose, fructose, xylose, sucrose, starch, maltose, and molasses) were analysed for highest protease production. Also, various nitrogen sources (beef extract, bovine serum albumin, casamino acids, casein, feather meal, gelatin, peptone, soybean meal, and yeast extract) were scrutinized for enhanced alkaline protease production. For this, each nitrogen ingredient (1\%) was separately added to the basal medium containing (g/L): starch, $20 ; \mathrm{KH}_{2} \mathrm{PO}_{4}, 1 ; \mathrm{MgSO}_{4} \cdot 7 \mathrm{H}_{2} \mathrm{O}, 0.05 ; \mathrm{CaCl}_{2}, 1 ; \mathrm{Na}_{2} \mathrm{CO}_{3}, 8$. The effect of medium supplementations with different concentrations of glucose $(0-2 \% \mathrm{w} / \mathrm{v})$, starch $(0-2 \% \mathrm{w} / \mathrm{v})$, soybean meal (0-2\% w/v), sodium carbonate (0-1\% w/v), $\mathrm{KH}_{2} \mathrm{PO}_{4}(0-$ $0.2 \% \mathrm{w} / \mathrm{v})$, and $\mathrm{CaCl}_{2}(0-0.2 \% \mathrm{w} / \mathrm{v})$ were evaluated under similar conditions.

2.6. Optimization of Physical Parameters for Protease Production. The effect of $\mathrm{pH}$ on growth and protease production was examined by growing the strain in a medium containing (g/L): soybean meal, 10; starch, 20; $\mathrm{KH}_{2} \mathrm{PO}_{4}, 1 ; \mathrm{MgSO}_{4} \cdot 7 \mathrm{H}_{2} \mathrm{O}$, $0.05 ; \mathrm{CaCl}_{2}, 1$; at $37^{\circ} \mathrm{C}$ and $100 \mathrm{rpm}$ at varying $\mathrm{pH}(7.0,8.0$, $9.0,10.0$, and 12.0). A separately sterilized sodium carbonate $(0.2-1.0 \% \mathrm{w} / \mathrm{v})$ was used to adjust alkaline $\mathrm{pH}$ of the medium. The influence of temperature $\left(30-60^{\circ} \mathrm{C}\right)$ was analysed for growth and protease secretion in the same medium discussed above, at $\mathrm{pH} 10.0$, for $48 \mathrm{~h}$. The effect of agitation on growth and protease production was also examined by growing the strain in medium at $\mathrm{pH} 10.0,37^{\circ} \mathrm{C}$ for $48 \mathrm{~h}$ under various speeds of rotation $(0-200 \mathrm{rpm})$. For preparation of inoculum, a prepared suspension $(0.5$ absorbance at $660 \mathrm{~nm})$ was evaluated in the range of $2-10 \%(\mathrm{v} / \mathrm{v})$.

2.7. Growth and Protease Production Profile. The growth and protease production were examined in the optimized production medium containing (g/L): soybean meal, 15; starch, 10; $\mathrm{KH}_{2} \mathrm{PO}_{4}, 1 ; \mathrm{MgSO}_{4} \cdot 7 \mathrm{H}_{2} \mathrm{O}, 0.05 ; \mathrm{CaCl}_{2}, 1 ; \mathrm{Na}_{2} \mathrm{CO}_{3}, 8 ; \mathrm{pH} 10.0$ at $37^{\circ} \mathrm{C}$ and $100 \mathrm{rpm}$ by analyzing samples at $6 \mathrm{~h}$ intervals. In each experiment, cell density was determined by harvesting biomass after centrifugation (12,000 rpm, $4^{\circ} \mathrm{C}$ and $10 \mathrm{~min}$ ) and washing twice with cold distilled water. The washed biomass was dried under vacuum at room temperature until a constant weight was attained.

2.8. Statistical Analysis. Each experiment was carried out in triplicate set; results were presented as mean $\pm \mathrm{SD}$. The results were considered as statistically significant when $P<0.05$. The appropriate vertical error bars are displayed on each graph. The error bar values were based on standard deviations, calculated for each data point by using SigmaStat software and Microsoft Excel.

\section{Results and Discussion}

3.1. Identification of Strain. The potential organic solvent tolerant bacterial isolate UB2 was isolated from soil collected from petrol station (nearly 25 years old) located at Shirpur (Dist-Dhule), India $\left[21^{\circ} 21^{\prime} 0^{\prime \prime} \mathrm{N} / 74^{\circ} 53^{\prime} 0^{\prime \prime} \mathrm{E}\right]$. The sample soil was found moistened with gasoline and diesel due to spills 
TABLE 1: Morphological, cultural, and biochemical characteristics of UB2 strain.

\begin{tabular}{lc}
\hline Characteristic & Description \\
\hline (A) Morphological & Rod \\
Shape & Single \\
Arrangement & Gram positive \\
Gram stain & + \\
Motility & + \\
Endospore & + \\
Capsule & -
\end{tabular}

(B) Cultural

Growth temperature $\left({ }^{\circ} \mathrm{C}\right)$

15

25

37

40

42

45

55

65

Growth pH

5.0

6.0

7.0

8.0

9.0

10.0

11.0

$\mathrm{NaCl}$ (\% tolerance)

2.5

5.0

7.0

8.5

10.5

(C) Biochemical

Utilization of

Malonate

Ribose

Xylose

L-Arabinose

Glucosamine

Inositol

Glucose

Fructose

Mannitol

D-Sorbitol

Maltose

Trehalose

Melibiose

Sucrose

Cellobiose
TABLE 1: Continued.

\begin{tabular}{lc}
\hline Characteristic & Description \\
\hline Lactose & - \\
Melezitose & - \\
Raffinose & - \\
Inulin & - \\
Enzyme & \\
Amylase & + \\
Arginine dihydrolase & + \\
Catalase & + \\
Gelatinase & + \\
Lysine dehydrogenase & - \\
Nitrate reductase & - \\
Ornithine decarboxylase & - \\
Oxidase & + \\
Urease & - \\
\hline
\end{tabular}

and emits typical petroleum odour. Petrol consists mostly of aliphatic hydrocarbons. It also contains the aromatic hydrocarbons like toluene and benzene to increase its octane rating. Microorganisms present in petroleum contaminated soils and their role in the petroleum product degradation have been reported earlier [16, 17]. The present investigation has revealed the presence of solvent-tolerant, alkaliphilic bacteria in man-made, petroleum compound contaminated soil.

Morphological, cultural, and biochemical characteristics of UB2 strain are summarized in Table 1. On the basis of these characteristics, the newly isolated UB2 strain was identified as Bacillus circulans. This identification was further verified by the Biolog system at Microbial Type Culture Collection (MTCC), Chandigarh. The assigned MTCC accession number is 7942. The $16 \mathrm{~S}$ rRNA gene of strain UB2 was PCR amplified, purified PCR product sequenced and aligned by using BLAST analysis on the NCBI server (http://www.ncbi.nlm.nih.gov/BLAST). To confirm the identity of UB2, 888 bp 16S rRNA genes were sequenced, respectively, and submitted to the NCBI Gene bank (accession number UB2: GQ461354). For comparison, currently available sequences at NCBI were used and multiple sequence alignment performed by using Bioedit 7.0. The phylogenetic tree was generated; the result showed that UB2 is related to Bacillus spp. (Figure 1).

3.2. Effect of Various Organic Solvents on Isolated Strain. The effect of various organic solvents on the growth of Bacillus circulans was investigated by measuring the dry weight of the culture. Figure 2 showed the dry cell weight of strain B. circulans after $72 \mathrm{~h}$ cultivation in the presence of different organic solvents. The strain was able to grow in all solvents studied except chloroform. Organic solvents are usually toxic to microorganisms, but several bacteria tolerant to organic solvents and able to produce protease have been reported [11, 12, 18-21]. Generally, organic solvents are toxic to living organisms, because of their adverse effects on 


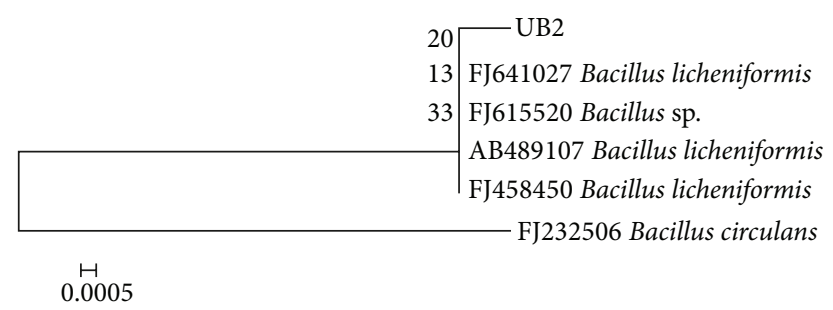

FIGURE 1: Phylogenetic tree of strain UB2 showing relatedness with Bacillus sp.

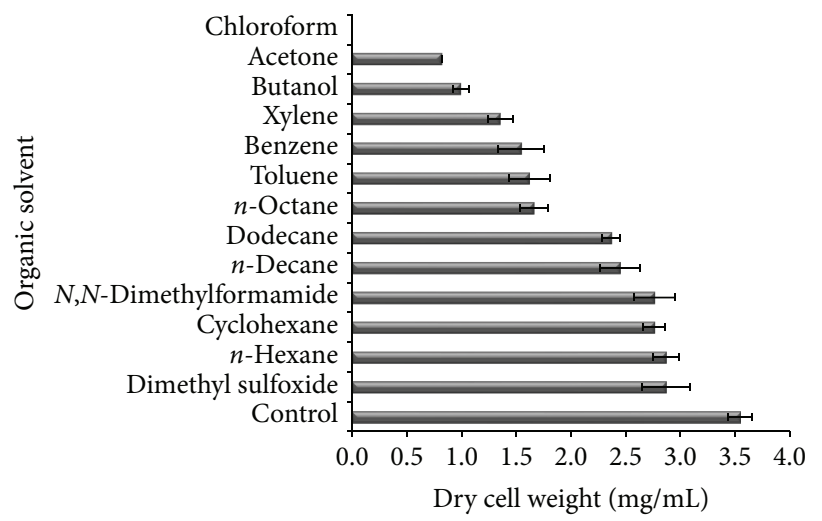

FIGURE 2: Dry cell weight of strain UB2 cultured in $100 \mathrm{~mL}$ of the nutrient liquid medium and $30 \mathrm{~mL}$ of organic solvent for $72 \mathrm{~h}$.

biological membranes while several researchers correlated solvent toxicity with the hydrophobic character of the solvent, expressed by the logarithm of its partition coefficient between octanol and water, denoted by a $\log P$ value $[12,22]$. Generally, solvents with $\log P$ values below 4 are considered extremely toxic as their degree of partitioning into the aqueous layer is higher [23]. Therefore, the presence of solvents may lead to a reduction in the growth. However, cells which are adapted to solvents can achieve the maximum growth rate in the presence of solvents.

Compared to the optimum growth in control, growth of B. circulans MTCC 7942 was (i) maximum in the presence of dodecane $(\log P=6.6), n$-decane $(\log P=5.6), n$-hexane $(\log$ $P=3.6)$, cyclohexane $(\log P=3.2), \mathrm{DMF}(\log P=-1.0)$, and DMSO $(\log P=-1.4)$, (ii) moderate in the presence of octane $(\log P=4.5)$, xylene $(\log P=3.1)$, benzene $(\log P=2.0)$, and toluene $(\log P=2.5)$, (iii) less in the presence of $n$ butanol $(\log P=0.8)$ and acetone $(\log P=-0.2)$. No growth was detected in the presence of chloroform $(\log P=2.0)$. The number of bacteria showing organic solvent tolerance is limited; the previously studied organic solvent-tolerant strains were Bacillus sp. [24], B. pumilus [8], B. licheniformis [25], and B. sphaericus [26]. Chloroform strongly inhibits the growth of $B$. circulans studied in present investigation; this might be due to a reduction in the affinity of the cells for nutrient and change in the structure of cell envelope [22]. Since the water-miscible solvents (DMF and DMSO) are usually used in organic reactions, $B$. circulans might have potential applications in nonaqueous reactions.
TABLE 2: Effect of nitrogen sources on protease production by $B$. circulans MTCC 7942.

\begin{tabular}{lcc}
\hline $\begin{array}{l}\text { Nitrogen } \\
\text { supplementation }(1 \%)^{\#}\end{array}$ & $\begin{array}{c}\text { Protease activity } \\
(\mathrm{U} / \mathrm{mL} \pm \mathrm{SD})\end{array}$ & $\begin{array}{c}\text { Specific activity } \\
(\mathrm{U} / \mathrm{mg} \pm \mathrm{SD})\end{array}$ \\
\hline Feather meal & $69.5 \pm 6.9$ & $222.6 \pm 21$ \\
Bovine serum albumin & $216.5 \pm 18.4$ & $635.9 \pm 55$ \\
Beef extract & $300.6 \pm 12.0$ & $905.7 \pm 41$ \\
Casein & $320.7 \pm 6.0$ & $884.2 \pm 114$ \\
Casamino acids & $329.1 \pm 13.3$ & $966 \pm 31$ \\
Yeast extract & $330.1 \pm 23.8$ & $875.8 \pm 163$ \\
Gelatin & $339.2 \pm 10.0$ & $1063.0 \pm 39$ \\
Peptone & $357.0 \pm 10.5$ & $1007.0 \pm 75$ \\
Soybean meal & $397.0 \pm 7.6$ & $1164.0 \pm 33$ \\
\hline
\end{tabular}

${ }^{\#}$ Basal medium containing (g/L): starch, 20; $\mathrm{KH}_{2} \mathrm{PO}_{4}, 1 ; \mathrm{MgSO}_{4} \cdot 7 \mathrm{H}_{2} \mathrm{O}, 0.05$; $\mathrm{CaCl}_{2}, 1 ; \mathrm{Na}_{2} \mathrm{CO}_{3}, 8$ and cultural parameters ( $\mathrm{pH} \mathrm{10.0)}$ ) at $37^{\circ} \mathrm{C}$ and $100 \mathrm{rpm}$.

\subsection{Effect of Various Media Ingredient on Growth and Protease} Production. Nitrogen is an essential component and has a profound effect on protease synthesis. Among various nitrogen sources, soybean meal exhibited noticeably higher protease production by $B$. circulans MTCC 7942 grown in basal medium containing $(\mathrm{g} / \mathrm{L})$ starch $20, \mathrm{KH}_{2} \mathrm{PO}_{4}, 1$; $\mathrm{MgSO}_{4} \cdot 7 \mathrm{H}_{2} \mathrm{O}, 0.05 ; \mathrm{CaCl}_{2}, 1, \mathrm{pH} 10$ at $37^{\circ} \mathrm{C}$ for $48 \mathrm{~h}$, followed in decreasing order by peptone, gelatin, yeast extract, casamino acids, casein, and beef extract. Poor production of protease was observed with bovine serum albumin and feather meal (Table 2). Although the nitrogen sources used 


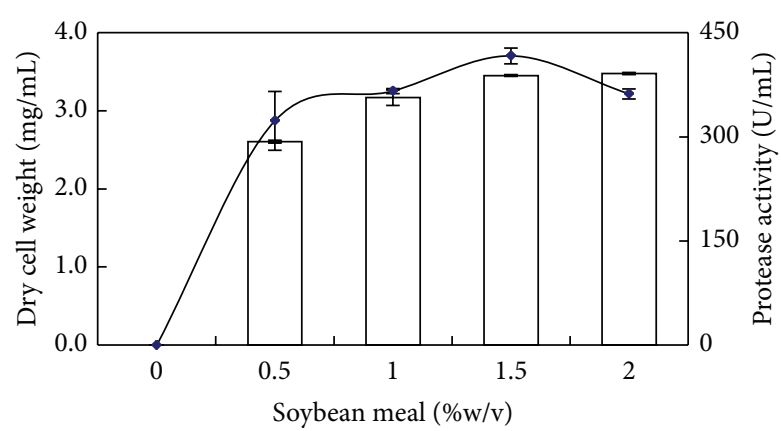

$\square$ Effect of ingredients of production medium on the growth $\multimap$ Optimum protease production

(a)

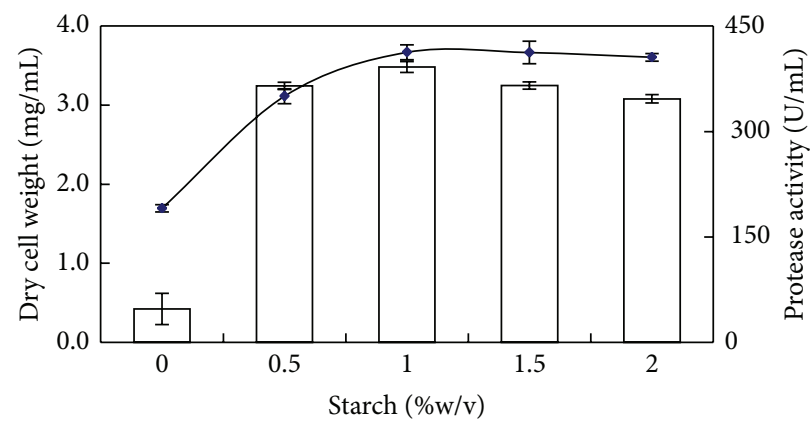

$\square$ Effect of ingredients of production medium on the growth $\rightarrow$ Optimum protease production

(b)

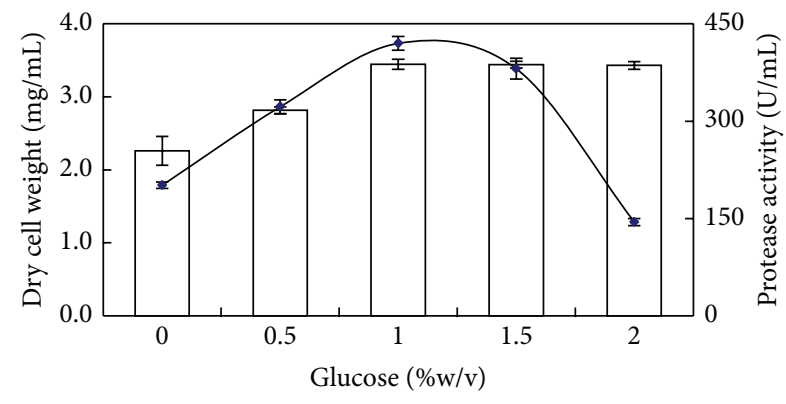

$\square$ Effect of ingredients of production medium on the growth
$\square$ Optimum protease production

(c)

FIGURE 3: Effect of ingredients of production medium on the growth and optimum protease production by B. circulans MTCC 7942 (a) soybean meal; (b) starch; and (c) glucose.

in this study contain varied concentration of total nitrogen (feather meal, 12\% w/w; gelatin, $18 \% \mathrm{w} / \mathrm{w}$; casein, $16 \% \mathrm{w} / \mathrm{w}$; and soybean meal, $8 \% \mathrm{w} / \mathrm{w}$ ), the soybean meal supported maximum protease yield. The complexity, solubility, and amino acid compositions are the factors probably affecting efficient utilization of these sources by the $B$. circulans. The free amino acids and peptides in digested nitrogen sources (peptone, yeast extract, casamino acids, and beef extract) could be responsible for the feedback repression of proteolytic system of the $B$. circulans. Hence, the most effective inducer of alkaline protease synthesis was soybean meal. Protease production by B. circulans MTCC 7942 attained maximum growth and maximum protease production at $1.5 \%$ soybean meal (Figure 3(a)).

Soybean meal being a comparatively cheap and readily available substrate, its industrial suitability for cost-effective production of protease at commercial level was a positive gain. Soybean meal was also reported to be a suitable nitrogen source for protease production [27], while a combination of casein $(1 \%)$ with soybean meal $(1.5 \%)$ gave the maximum protease production by Bacillus horikoshii [28]. On the contrary, the presence of yeast extract as a nitrogen source in the production medium had shown substantially enhanced protease production by Bacillus acidophilus subsp. halodurans [29]. Fujiwara et al. [30] recorded maximum enzyme production using a combination of $3.0 \%(\mathrm{w} / \mathrm{v})$ soybean meal and $1.5 \%(\mathrm{w} / \mathrm{v})$ bonito extract. Higher levels of protease production were reported from Bacillus pseudofirmus AL-89 and Nesterenkonia sp. AL-20, on feather meal [31].

Organic nitrogen medium alone was not sufficient for the production of protease; additional carbon source (glucose or starch) in the basal medium was essential for the optimum protease production of this strain. Protease production by $B$. circulans MTCC 7942 by employing various carbon sources is summarized in Table 3. The highest protease production of it was a function of glucose, maltose, and starch, followed by fructose and xylose. Further, optimum concentration of starch was evaluated by incorporating $0.5-2 \%(\mathrm{w} / \mathrm{v})$ in basal medium containing $(\mathrm{g} / \mathrm{L})$ soybean meal $10, \mathrm{KH}_{2} \mathrm{PO}_{4}$, $1 ; \mathrm{MgSO}_{4} \cdot 7 \mathrm{H}_{2} \mathrm{O}, 0.05 ; \mathrm{CaCl}_{2}, 1$. The optimum concentration of starch for protease production was 1.0\% (Figure 3(b)). Also, $0.5-2 \%$ glucose was analysed to find out the repression effect of it. The protease production of B. circulans MTCC 7942 was suppressed by glucose beyond $1.5 \%$ concentration (Figure 3(c)). Glucose and lactose were reported as effective carbon sources for protease production in Bacillus sp. AR009 [32] and B. licheniformis ATCC 21415 [33]. Similarly, increased level of protease production by B. pseudofirmus AL89 was observed upon addition of glucose [31]. 


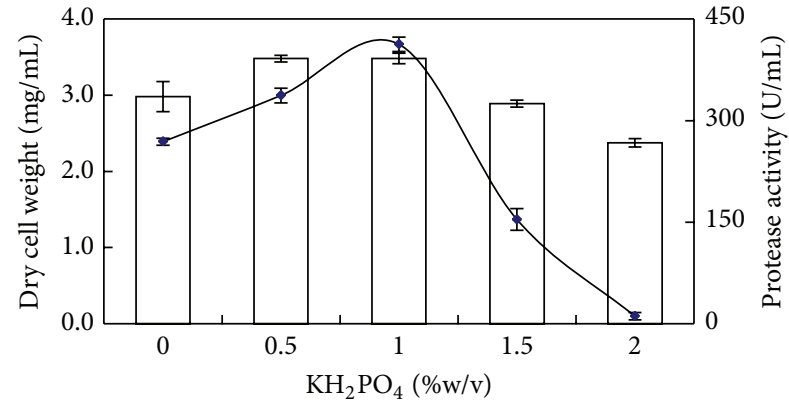

$\square$ Effect of ingredients of production medium on the growth $\rightarrow$ Optimum protease production

(a)

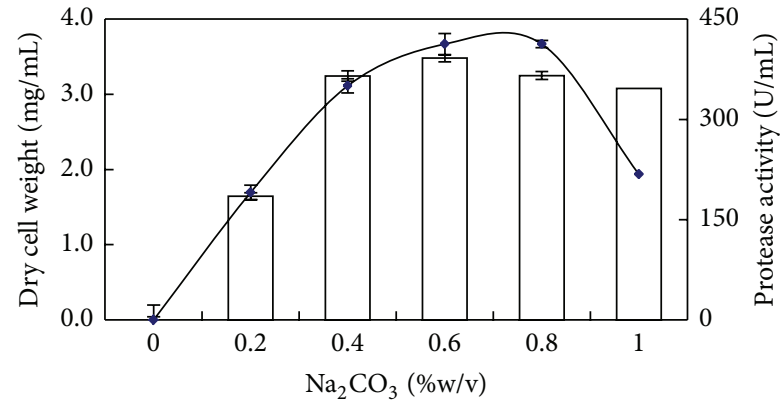

$\square$ Effect of ingredients of production medium on the growth $\longrightarrow$ Optimum protease production

(b)

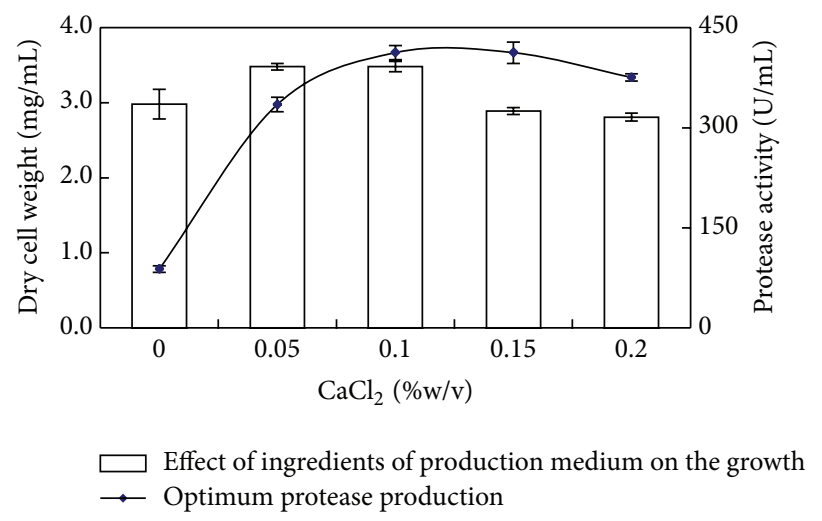

(c)

FIGURE 4: Effect of ingredients of production medium on the growth and optimum protease production by B. circulans MTCC 7942 (a) $\mathrm{KH}_{2} \mathrm{PO}_{4}$, (b) $\mathrm{Na}_{2} \mathrm{CO}_{3}$, and (c) $\mathrm{CaCl}_{2}$.

TABLE 3: Effect of carbon sources on protease production by $B$. circulans MTCC 7942.

\begin{tabular}{lcc}
\hline Carbon source $(1 \%)^{\#}$ & $\begin{array}{c}\text { Protease activity } \\
(\mathrm{U} / \mathrm{mL} \pm \mathrm{SD})\end{array}$ & $\begin{array}{c}\text { Specific activity } \\
(\mathrm{U} / \mathrm{mg} \pm \mathrm{SD})\end{array}$ \\
\hline Control & $201.3 \pm 10$ & $621.6 \pm 79$ \\
Xylose & $223.3 \pm 13$ & $665.7 \pm 58$ \\
Fructose & $265.9 \pm 10$ & $940 \pm 80$ \\
Sucrose & $359.2 \pm 7$ & $1033 \pm 32$ \\
Molasses & $379.5 \pm 8$ & $1077 \pm 43$ \\
Maltose & $394.2 \pm 4$ & $1144 \pm 22$ \\
Glucose & $394.8 \pm 8$ & $1158 \pm 42$ \\
Starch & $406.6 \pm 5$ & $1205 \pm 43$ \\
${ }^{\#}{ }_{\text {Basal medium containing }}(\mathrm{g} / \mathrm{L}):$ soybean meal, & $10 ; \mathrm{KH}_{2} \mathrm{PO}_{4}, \quad 1 ;$ \\
$\mathrm{MgSO}_{4} \cdot 7 \mathrm{H}_{2} \mathrm{O}, 0.05 ; \mathrm{CaCl}_{2}, 1 ; \mathrm{Na}_{2} \mathrm{CO}_{3}, 8$, and cultural parameters $(\mathrm{pH} 10.0)$ \\
at $37^{\circ} \mathrm{C}$ and $100 \mathrm{rpm}$.
\end{tabular}

The effect of phosphate ions was examined for enhanced growth and production of protease by $B$. circulans MTCC 7942 (Figure 4(a)). In most studies, potassium phosphate has been used as a source of phosphate and buffering component of the medium [30,34-36]. Phosphate at the concentration of $2 \mathrm{~g} / \mathrm{L}$ was found optimal for protease production by Bacillus firmus, while further supplementation showed an inhibition of cell growth and repression in protease production. Also, phosphate concentration above $4 \mathrm{~g} / \mathrm{L}$ leads to precipitation of the medium on autoclaving [34]. On the contrary, Phadatare et al. [37] showed that salts did not have any effect on alkaline protease production from Conidiobolus coronatus.

The effect of sodium carbonate on the growth and protease production by B. circulans MTCC 7942 was examined (Figure 4(b)). Sodium carbonate was detected as essential media component as in the absence of its growth does not occur. The optimum concentration which supported maximum growth and protease secretion was $0.6 \%(\mathrm{w} / \mathrm{v})$. The role of $\mathrm{Na}_{2} \mathrm{CO}_{3}$ was to maintain an alkaline $\mathrm{pH}$ of the medium and ensure protease production was detected in B. circulans. An optimal protease production was observed at a concentration of $0.8 \%(\mathrm{w} / \mathrm{v})$ sodium carbonate [38]. Horikoshi and Akiba [39] used sodium carbonate to adjust $\mathrm{pH}$ of the medium for alkaline protease production, while Genckal and Tari [40] used $6 \mathrm{M} \mathrm{NaOH}$ to set the alkaline $\mathrm{pH}$ of Horikoshi media for alkaline protease production using Bacillus L18 and L21. During production of protease, sodium carbonate incorporation as a source of alkalinity to their growth media is routinely practised so as to simulate the natural ecological habitat and enhance their growth. Calcium chloride was found to be a crucial component of production media for alkaline protease production by B. circulans MTCC 7942 


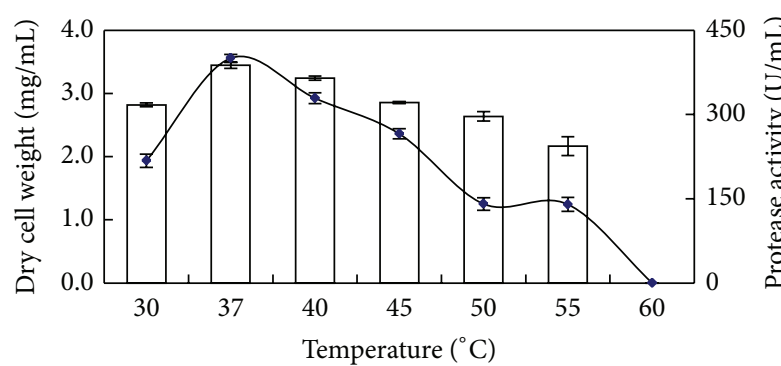

$\square$ Effect of physical parameters on the growth $\rightarrow$ Optimum protease production

(a)

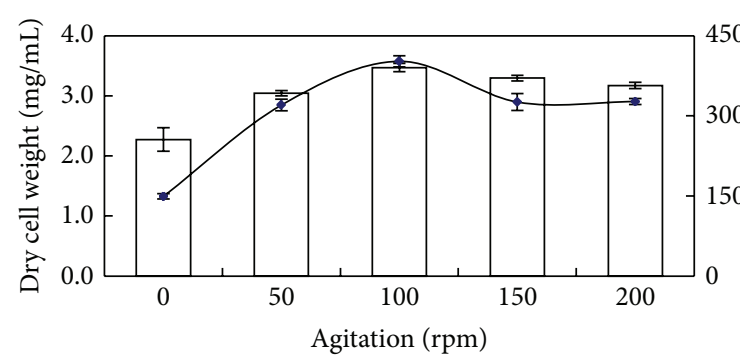

$\square$ Effect of physical parameters on the growth $\rightarrow$ Optimum protease production

(c)

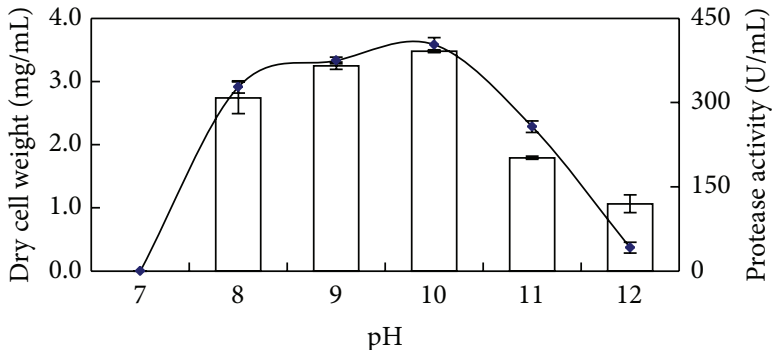

Effect of physical parameters on the growth $\rightarrow$ Optimum protease production

(b)

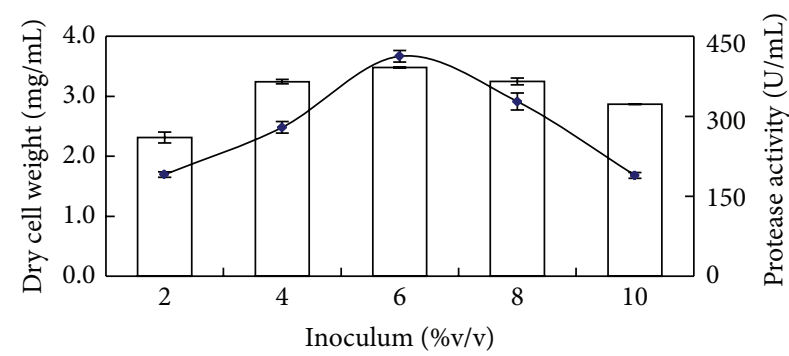

$\square$ Effect of physical parameters on the growth
$\rightarrow$ Optimum protease production

(d)

FIGURE 5: Effect of physical parameters on the growth and optimum protease production by B. circulans MTCC 7942 (a) temperature; (b) $\mathrm{pH}$; (c) agitation; and (d) inoculum.

(Figure $4(\mathrm{c})$ ). $\mathrm{CaCl}_{2}$ has a vital effect in protease production by $B$. circulans. Similarly, $\mathrm{CaCl}_{2}$ accelerated the production of protease in Streptomyces [41], Bacillus sp. PCSIR EA-3 [42].

\subsection{Effect of Physical Parameters on Growth and Enzyme} Production. The effect of incubation temperature on growth and protease production by $B$. circulans MTCC 7942 was examined. Although strain could grow in broad temperature range $30-55^{\circ} \mathrm{C}$, maximum growth and protease production was detected at $37^{\circ} \mathrm{C}$ suggesting thermotolerant nature of strain. The strain secreted alkaline protease even at $50-$ $55^{\circ} \mathrm{C}$, but its optimum secretion $(401.08 \mathrm{U} / \mathrm{mL})$ was at $37^{\circ} \mathrm{C}$ (Figure 5(a)). Several earlier reports have indicated incubation temperature as a critical parameter for regulating the synthesis and secretion of alkaline protease by microbes $[43,44]$, by affecting (i) energy metabolism and oxygen uptake [45], (ii) translational synthesis of protein [46], and (iii) the physical properties of cell membrane [20]. Bacillus sp. secreted proteases over a wide range of temperature $\left(30-60^{\circ} \mathrm{C}\right)[2,28,39]$. A critical assessment with the previous reports on the characteristics of alkaliphilic Bacillus strains producing alkaline proteases, revealed that several alkaliphilic Bacillus strains have temperature optima between 30 and $37^{\circ} \mathrm{C}$ and are mostly of mesophilic type [33, 47-49].

The $\mathrm{pH}$ of the medium has an effect on alkaline protease production. B. circulans MTCC 7942 grew maximally in the $\mathrm{pH}$ range of 8.0 to 11.0 ; no growth was detected at $\mathrm{pH}$
7.0, indicating that the strain was an obligate alkaliphile. Although at pH 11.0 strain produced an appreciable protease yield, the optimum $\mathrm{pH}$ value for growth and alkaline protease production was $\mathrm{pH} 10.0$ It secretes $403.2 \pm 12 \mathrm{U} / \mathrm{mL}$ protease at $\mathrm{pH} 10.0$ (Figure 5(b)). Interactions between the metabolic reactions and genetic regulatory mechanism(s), product and byproduct formation in the bioprocess for alkaline protease production are dependent on $\mathrm{pH}$. The $\mathrm{pH}$ also influences the transport of various nutrient components across the cell membranes, which in turn sustain the cell growth and the product formation. Similar results were obtained by Rahman et al. [50] who reported maximum protease production in B. stearothermophilus at $\mathrm{pH} 10$ and $60^{\circ} \mathrm{C}$. Alkaline protease production was reported using $B$. circulans under solid state fermentations at $\mathrm{pH} 10.0$ [51, 52], Bacillus sp. B001 [47] at $\mathrm{pH}$ 10 and $B$. licheniformis MP1 at $\mathrm{pH} 8$ [48].

Effect of agitation on B. circulans MTCC 7942 was analyzed at $0,50,100,150$, and $200 \mathrm{rpm}$ for $48 \mathrm{~h}$. An increase in agitation speed (rpm) enhanced the growth of B. circulans MTCC 7942 with an increase in protease production up to $100 \mathrm{rpm}$. However, further increase in agitation did not contribute to the growth and protease production. Hence, the optimum agitation speed for growth and protease production was $100 \mathrm{rpm}$ (Figure 5(c)). Agitation enhanced the protease production in this case, probably due to (i) better nutrient transfer rate, (ii) an increase in the solubility of oxygen through the mixing of the contents, (iii) dispersion of cell aggregates, and (iv) enhanced aerobic metabolism during 


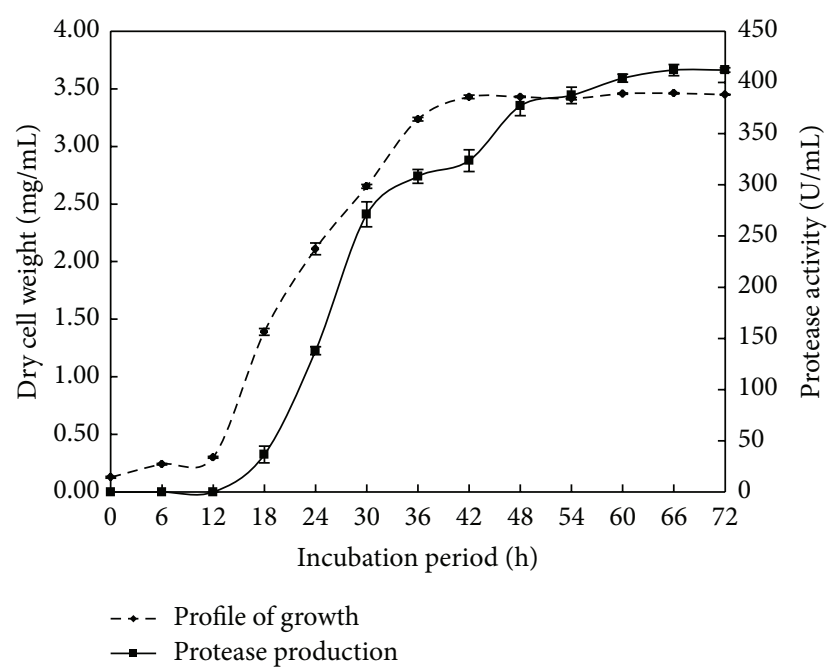

Figure 6: Profile of growth and protease production of B. circulans MTCC 7942 as a function of time.

fermentation [40, 49]. On the contrary, Frankena et al. [45] reported an increase in protease production in B. licheniformis when oxygen was limited. Production of alkaline protease was enhanced in (i) Bacillus sp. when agitated at $150 \mathrm{rpm}$ [53] and (ii) B. licheniformis ATCC 21415 when the agitation rate increased from 250 to $400 \mathrm{rpm}$ [33], while low or no agitation caused a drastic reduction in protease production in B. firmus [34] and Bacillus mojavensis A21 [54]. Compared to previously reported Bacillus strains, the studied strain B. circulans MTCC 7942 did not require higher speed (more than $100 \mathrm{rpm}$ ) for protease production, probably due to little requirement for oxygen.

3.5. Inoculum Optimization. It is essential to establish an effective inoculum development program, regardless of the scale of fermentation. Such program not only aids consistency on a small scale but is invaluable in scaling up the fermentation for providing homogenous, contamination free inoculum. The inoculum size had an impact on cell growth, minimization of contamination, and enzyme synthesis, depending on the characteristics of the strains. For preparation of inoculum, a suspension was prepared by mixing pregrown $B$. circulans MTCC 7942 with saline to achieve 0.5 absorbance at $660 \mathrm{~nm}$. The effect of inoculum size was studied in the range $2-10 \%(\mathrm{v} / \mathrm{v})$. Growth and protease production of $B$. circulans MTCC 7942 was maximum at $6 \%(\mathrm{v} / \mathrm{v})$ inoculum incubated for $48 \mathrm{~h}$ (Figure 5(d)). An inoculation of $2-5 \%$ culture was an optimum value for the Bacillus type of strains reported in the literature, which supported our findings. Higher inoculum sizes might be responsible for lack of oxygen and early nutrient depletion. These include $1.0 \%(\mathrm{v} / \mathrm{v})$ for Bacillus sp. [55], 5.0\% (v/v) for B. licheniformis ATCC 21415 [33], and 10.0\% (v/v) for Bacillus sp. [56].

\section{Conclusions}

Production of alkaline protease from solvent-tolerant, alkaliphilic B. circulans MTCC 7942, isolated from hydrocarbon contaminated soil, was reported. A time course study was performed to determine bacterial growth and protease production of B. circulans MTCC 7942. Figure 6 shows that (i) logarithmic growth phase commenced at $12 \mathrm{~h}$ and continued thereafter until $36 \mathrm{~h}$, (ii) maximum growth in biomass was attained until $48 \mathrm{~h}$, (iii) protease production initiated just before $24 \mathrm{~h}$ continued until $60 \mathrm{~h}$, attains maximum protease activity $(412 \mathrm{U} / \mathrm{mL})$, and (iv) remained steady in the medium even after $72 \mathrm{~h}$, indicating its resistance to inactivation and stability of protease. This is a commercially desirable trait for maximum recovery during processing.

\section{Acknowledgments}

Ulhas Patil is thankful to the University Grant Commission, New Delhi, and UGC-WRO, Pune, for financial support under Minor Research Scheme (47-1326/10-WRO). Authors are thankful to Dr. Yogesh Shouche, MCC, NCCS, Pune, for $16 \mathrm{~S}$ rRNA sequencing of strain.

\section{References}

[1] Marketwire, 2012, http://www.marketwired.com/.

[2] R. Gupta, Q. Beg, and P. Lorenz, "Bacterial alkaline proteases: molecular approaches and industrial applications," Applied Microbiology and Biotechnology, vol. 59, no. 1, pp. 15-32, 2002.

[3] J. Eichler, "Biotechnological uses of archaeal extremozymes," Biotechnology Advances, vol. 19, no. 4, pp. 261-278, 2001.

[4] F. Bordusa, "Proteases in organic synthesis," Chemical Reviews, vol. 102, no. 12, pp. 4817-4867, 2002.

[5] M. N. Gupta and I. Roy, "Enzymes in organic media: forms, functions and applications," European Journal of Biochemistry, vol. 271, no. 13, pp. 2575-2583, 2004.

[6] H. J. Heipieper, G. Neumann, S. Cornelissen, and F. Meinhardt, "Solvent-tolerant bacteria for biotransformations in two-phase fermentation systems," Applied Microbiology and Biotechnology, vol. 74, no. 5, pp. 961-973, 2007.

[7] A. Gupta and S. K. Khare, "A protease stable in organic solvents from solvent tolerant strain of Pseudomonas aeruginosa," Bioresource Technology, vol. 97, no. 15, pp. 1788-1793, 2006.

[8] R. N. Z. R. A. Rahman, S. Mahamad, A. B. Salleh, and M. Basri, "A new organic solvent tolerant protease from Bacillus pumilus 115b," Journal of Industrial Microbiology and Biotechnology, vol. 34, no. 7, pp. 509-517, 2007.

[9] K. K. Doddapaneni, R. Tatineni, R. N. Vellanki et al., "Purification and characterization of a solvent and detergent-stable novel protease from Bacillus cereus," Microbiological Research, vol. 164, no. 4, pp. 383-390, 2009.

[10] U. Patil and A. Chaudhari, "Optimal production of alkaline protease from solvent-tolerant alkalophilic Pseudomonas aeruginosa MTCC 7926," Indian Journal of Biotechnology, vol. 10, no. 3, pp. 329-339, 2011.

[11] A. Badoei-Dalfard and Z. Karami, "Screening and isolation of an organic solvent tolerant-protease from Bacillus sp. JER02: activity optimization by response surface methodology," Journal of Molecular Catalysis B, vol. 89, no. 2, pp. 15-23, 2013. 
[12] J. Sambrook, E. Fritsch, and T. Maniatis, Molecular Cloning, A Laboratory Manual, Cold Spring Harbor Laboratory, New York, NY, USA, 2nd edition, 1989.

[13] H. Ogino, K. Yasui, T. Shiotani, T. Ishihara, and H. Ishikawa, "Organic solvent-tolerant bacterium which secretes an organic solvent- stable proteolytic enzyme," Applied and Environmental Microbiology, vol. 61, no. 12, pp. 4258-4262, 1995.

[14] T. Nakanishi, Y. Matsumura, N. Minamiura, and T. Yamamoto, "Action and specificity of Streptomyes alkalophilic proteinase," Agricultural and Biological Chemistry, vol. 38, no. 1, pp. 37-44, 1974.

[15] O. Lowry, N. Rosebrough, V. Farr, and R. Randall, "Protein measurement with the Folin phenol reagent," The Journal of Biological Chemistry, vol. 193, no. 1, pp. 265-275, 1951.

[16] V. Riis, D. Miethe, and W. Babel, "Degradation of refinery products and oils from polluted sites by the autochthonous microorganisms of contaminated and pristine soils," Microbiological Research, vol. 150, no. 3, pp. 323-330, 1995.

[17] J. Wyszkowska and J. Kucharski, "Correlation between number of microbes and degree of soil contamination by petrol," Polish Journal of Environmental Studies, vol. 10, no. 3, pp. 175-181, 2001.

[18] C. J. Hun, R. N. Z. A. Rahman, A. B. Salleh, and M. Basri, "A newly isolated organic solvent tolerant Bacillus sphaericus $205 \mathrm{y}$ producing organic solvent-stable lipase," Biochemical Engineering Journal, vol. 15, no. 2, pp. 147-151, 2003.

[19] A. Gupta, I. Roy, S. K. Khare, and M. N. Gupta, "Purification and characterization of a solvent stable protease from Pseudomonas aeruginosa PseA," Journal of Chromatography A, vol. 1069, no. 2, pp. 155-161, 2005.

[20] R. N. Z. A. Rahman, L. P. Geok, M. Basri, and A. B. Salleh, "Physical factors affecting the production of organic solventtolerant protease by Pseudomonas aeruginosa strain K," Bioresource Technology, vol. 96, no. 4, pp. 429-436, 2005.

[21] U. Patil and A. Chaudhari, "Purification and characterization of solvent-tolerant, thermostable, alkaline metalloprotease from alkalophilic Pseudomonas aeruginosa MTCC 7926," Journal of Chemical Technology and Biotechnology, vol. 84, no. 9, pp. 12551262, 2009.

[22] S. Isken, A. Derks, P. F. G. Wolffs, and J. A. M. De Bont, "Effect of organic solvents on the yield of solvent-tolerant Pseudomonas putida S12," Applied and Environmental Microbiology, vol. 65, no. 6, pp. 2631-2635, 1999.

[23] Y. N. Sardessai and S. Bhosle, "Industrial potential of organic solvent tolerant bacteria," Biotechnology Progress, vol. 20, no. 3, pp. 655-660, 2004.

[24] H. Shimogaki, K. Takeuchi, T. Nishino et al., "Purification and properties of a novel surface-active agent- and alkaline-resistant protease from Bacillus sp. Y," Agricultural and Biological Chemistry, vol. 55, no. 9, pp. 2251-2258, 1991.

[25] R. Sareen and P. Mishra, "Purification and characterization of organic solvent stable protease from Bacillus licheniformis RSP09-37," Applied Microbiology and Biotechnology, vol. 79, no. 3, pp. 399-405, 2008.

[26] W. Fang, J. Feng, Y. Fan et al., "Expressing a fusion protein with protease and chitinase activities increases the virulence of the insect pathogen Beauveria bassiana," Journal of Invertebrate Pathology, vol. 102, no. 2, pp. 155-159, 2009.

[27] S. Sen and T. Satyanarayana, "Optimization of alkaline protease production by thermophilic Bacillus licheniformis S-40," Indian Journal of Microbiology, vol. 33, no. 1, pp. 43-47, 1993.
[28] H.-S. Joo, C. G. Kumar, G.-C. Park, K. T. Kim, S. R. Paik, and C.S. Chang, "Optimization of the production of an extracellular alkaline protease from Bacillus horikoshii," Process Biochemistry, vol. 38, no. 2, pp. 155-159, 2002.

[29] Y. Takii, N. Kuriyama, and Y. Suzuki, "Alkaline serine protease produced from citric acid by Bacillus alcalophilus subsp. halodurans KP 1239," Applied Microbiology and Biotechnology, vol. 34, no. 1, pp. 57-62, 1990.

[30] N. Fujiwara, K. Yamamoto, and A. Masui, "Utilization of a thermostable alkaline protease from an alkalophilic thermophile for the recovery of silver from used X-ray film," Journal of Fermentation and Bioengineering, vol. 72, no. 4, pp. 306-308, 1991.

[31] A. Gessesse, R. Hatti-Kaul, B. A. Gashe, and B. Mattiasson, "Novel alkaline proteases from alkaliphilic bacteria grown on chicken feather," Enzyme and Microbial Technology, vol. 32, no. 5, pp. 519-524, 2003.

[32] A. Gessesse, "The use of nug meal as a low-cost substrate for the production of alkaline protease by the alkaliphilic Bacillus sp. AR-009 and some properties of the enzyme," Bioresource Technology, vol. 62, no. 1-2, pp. 59-61, 1997.

[33] S. S. Mabrouk, A. M. Hashem, N. M. A. El-Shayeb, A.-M. S. Ismail, and A. F. Abdel-Fattah, "Optimization of alkaline protease productivity by Bacillus licheniformis ATCC 21415," Bioresource Technology, vol. 69, no. 2, pp. 155-159, 1999.

[34] S.-H. Moon and S. J. Parulekar, "A parametric study of protease production in batch and fed-batch cultures of Bacillus firmus," Biotechnology and Bioengineering, vol. 37, no. 5, pp. 467-483, 1991.

[35] W. Mao, R. Pan, and D. Freedman, "High production of alkaline protease by Bacillus licheniformis in a fed-batch fermentation using a synthetic medium," Journal of Industrial Microbiology, vol. 11, no. 1, pp. 1-6, 1992.

[36] U. Hubner, U. Bock, and K. Schugerl, "Production of alkaline serine protease subtilisin Carlsberg by Bacillus licheniformis on complex medium in a stirred tank reactor," Applied Microbiology and Biotechnology, vol. 40, no. 2-3, pp. 182-188, 1993.

[37] S. Phadatare, M. C. Srinivasan, and M. Deshpande, "Evidence for the involvement of serine protease in the conidial discharge of Conidiobolus coronatus," Archives of Microbiology, vol. 153, no. 1, pp. 47-49, 1989.

[38] H.-S. Joo and C.-S. Chang, "Production of an oxidant and SDSstable alkaline protease from an alkaophilic Bacillus clausii I-52 by submerged fermentation: feasibility as a laundry detergent additive," Enzyme and Microbial Technology, vol. 38, no. 1-2, pp. 176-183, 2006.

[39] K. Horikoshi and T. Akiba, Alkalophilic Microorganisms: A New Microbial World, Springer, Berlin, Germany, 1982.

[40] H. Genckal and C. Tari, "Alkaline protease production from alkalophilic Bacillus sp. isolated from natural habitats," Enzyme and Microbial Technology, vol. 39, no. 4, pp. 703-710, 2006.

[41] D. S. Chahal and S. K. Nanda, "Influence of the nature and concentration of calcium ions on production of activity of protease of Streptomyces spp," Proceeding Indian Notational Science Academy, vol. 41, pp. 435-439, 1975.

[42] S. A. Ul Qadar, E. Shireen, S. Iqbal, and A. Anwar, "Optimization of protease production from newly isolated strain of Bacillus sp. PCSIR EA-3," Indian Journal of Biotechnology, vol. 8, no. 3, pp. 286-290, 2009.

[43] K. Peek, R. M. Daniel, C. Monk, L. Parker, and T. Coolbear, "Purification and characterization of a thermostable proteinase 
isolated from Thermus sp. strain Rt41A," European Journal of Biochemistry, vol. 207, no. 3, pp. 1035-1044, 1992.

[44] L. S. Engel, J. M. Hill, A. R. Caballero, L. C. Green, and R. J. O'Callaghan, "Protease IV, a unique extracellular protease and virulence factor from Pseudomonas aeruginosa," The Journal of Biological Chemistry, vol. 273, no. 27, pp. 16792-16797, 1998.

[45] J. Frankena, G. M. Koningstein, H. W. van Verseveld, and A. H. Stouthamer, "Effect of different limitations in chemostat cultures on growth and production of exocellular protease by Bacillus licheniformis," Applied Microbiology and Biotechnology, vol. 24, no. 2, pp. 106-112, 1986.

[46] J. Votruba, J. Pazlarova, M. Dvorakova et al., "External factors involved in the regulation of synthesis of an extracellular proteinase in Bacillus megaterium: effect of temperature," Applied Microbiology and Biotechnology, vol. 35, no. 3, pp. 352-357, 1991.

[47] A. Deng, J. Wu, Y. Zhang, G. Zhang, and T. Wen, "Purification and characterization of a surfactant-stable high-alkaline protease from Bacillus sp. B001," Bioresource Technology, vol. 101, no. 18, pp. 7100-7106, 2010.

[48] K. Jellouli, O. Ghorbel-Bellaaj, H. B. Ayed, L. Manni, R. Agrebi, and M. Nasri, "Alkaline-protease from Bacillus licheniformis MP1: purification, characterization and potential application as a detergent additive and for shrimp waste deproteinization," Process Biochemistry, vol. 46, no. 6, pp. 1248-1256, 2011.

[49] P. Çalik, E. Bilir, G. Çalik, and T. H. Özdamar, "Influence of pH conditions on metabolic regulations in serine alkaline protease production by Bacillus licheniformis," Enzyme and Microbial Technology, vol. 31, no. 5, pp. 685-697, 2002.

[50] R. N. Z. R. A. Rahman, M. Basri, and A. B. Salleh, "Thermostable alkaline protease from Bacillus stearothermophilus F1; nutritional factors affecting protease production," Annals of Microbiology, vol. 53, no. 2, pp. 199-210, 2003.

[51] R. S. Prakasham, C. Subba Rao, R. Sreenivas Rao, and P. N. Sarma, "Alkaline protease production by an isolated Bacillus circulans under solid-state fermentation using agroindustrial waste: process parameters optimization," Biotechnology Progress, vol. 21, no. 5, pp. 1380-1388, 2005.

[52] C. Subba Rao, T. Sathish, P. Ravichandra, and R. S. Prakasham, "Characterization of thermo- and detergent stable serine protease from isolated Bacillus circulans and evaluation of ecofriendly applications," Process Biochemistry, vol. 44, no. 3, pp. 262-268, 2009.

[53] C. A. Razak, S. W. Tang, M. Basri, and A. B. Salleh, "Preliminary study on the production of extracellular protease from a newly isolated Bacillus sp. (no. 1) and the physical factors affecting its production," Pertanika Journal of Science \& Technology, vol. 5, no. 2, pp. 169-177, 1997.

[54] A. Haddar, N. Fakhfakh-Zouari, N. Hmidet, F. Frikha, M. Nasri, and A. S. Kamoun, "Low-cost fermentation medium for alkaline protease production by Bacillus mojavensis A21 using hulled grain of wheat and sardinella peptone," Journal of Bioscience and Bioengineering, vol. 110, no. 3, pp. 288-294, 2010.

[55] S. Mehrotra, P. K. Pandey, R. Gaur, and N. S. Darmwal, "The production of alkaline protease by a Bacillus species isolate," Bioresource Technology, vol. 67, no. 2, pp. 201-203, 1999.

[56] S. Jasvir, N. Gill, G. Devasahayam, and D. K. Sahoo, "Studies on alkaline protease produced by Bacillus sp. NG312," Applied Biochemistry and Biotechnology A, vol. 76, no. 1, pp. 57-63, 1999. 

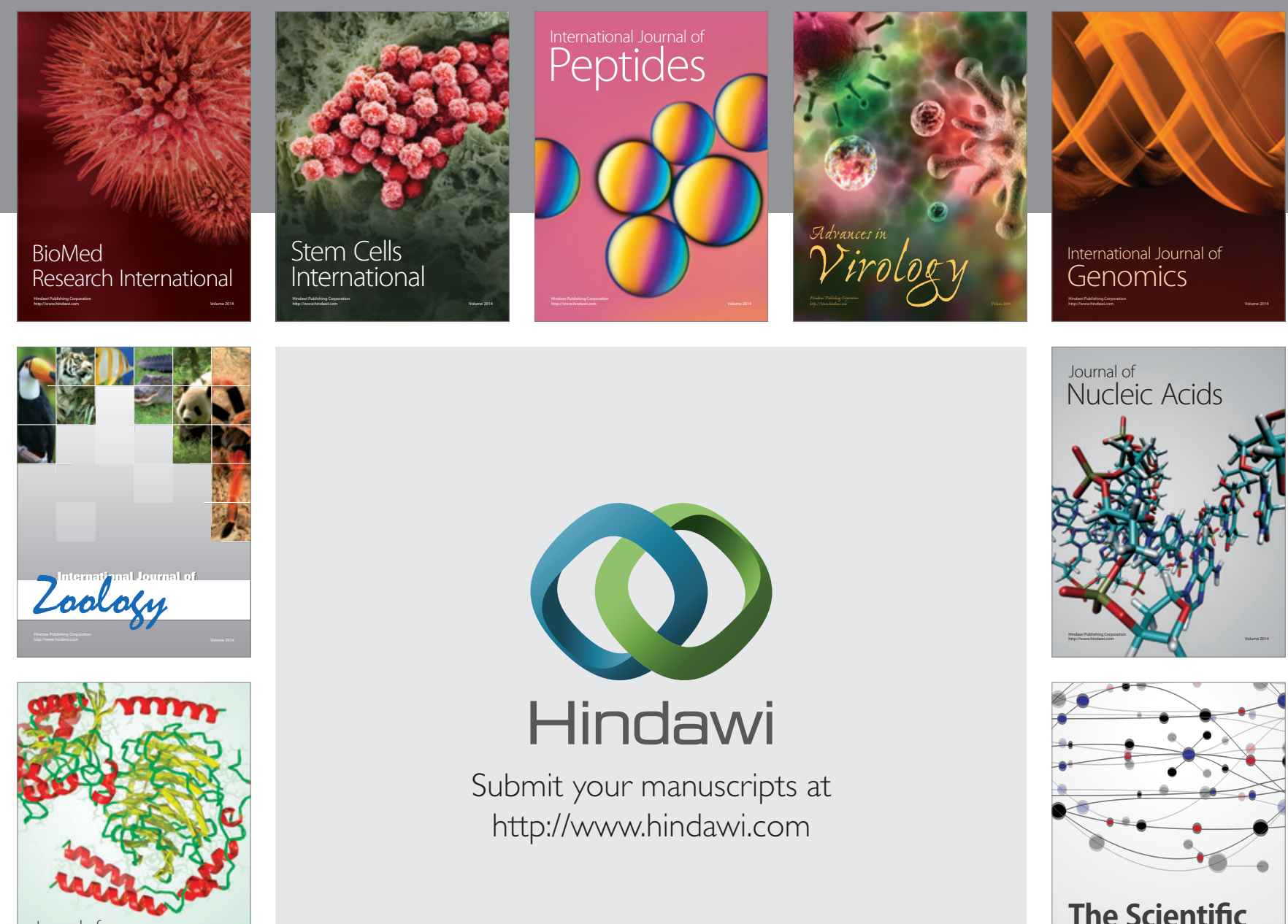

Submit your manuscripts at

http://www.hindawi.com

Journal of
Signal Transduction
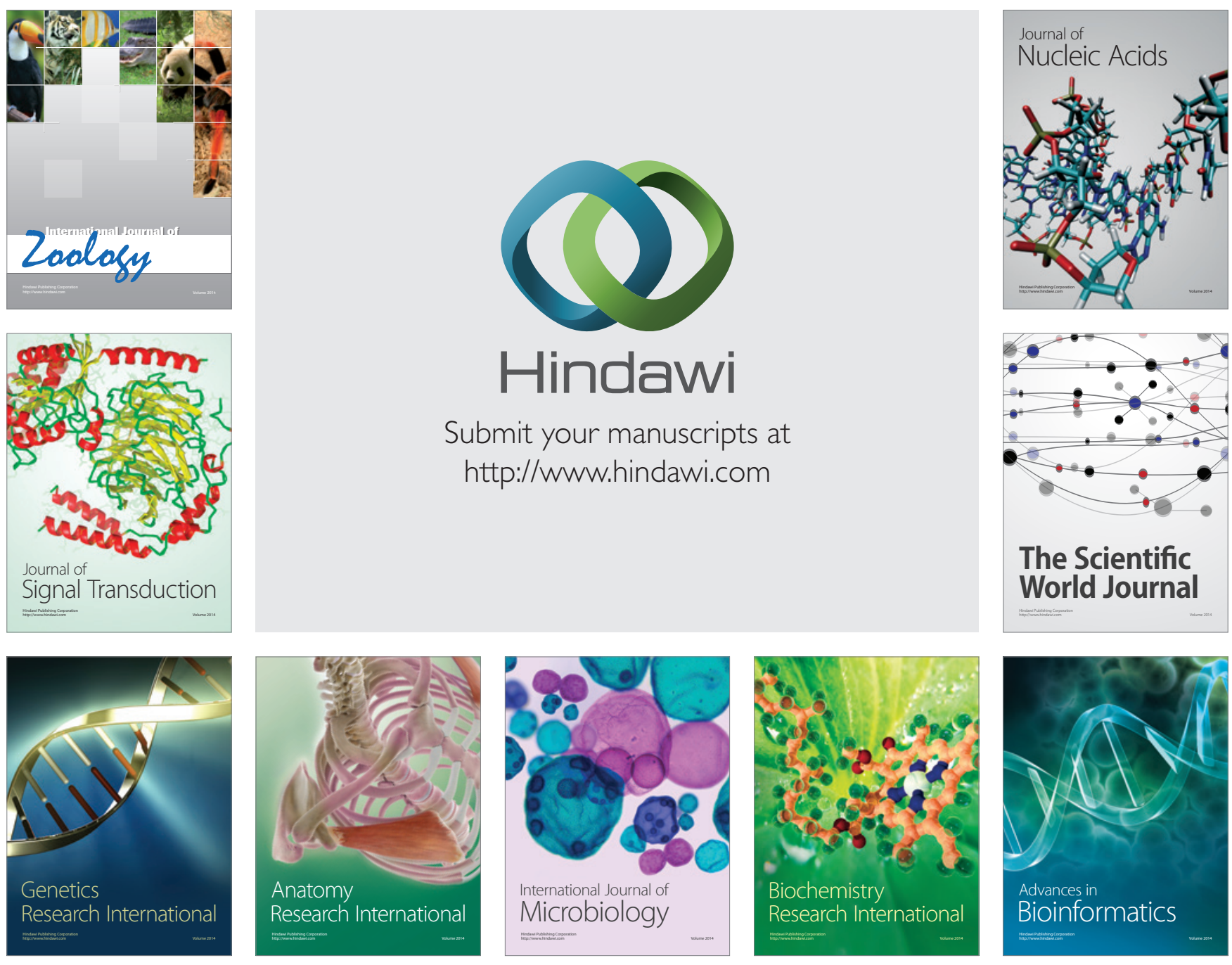

The Scientific World Journal
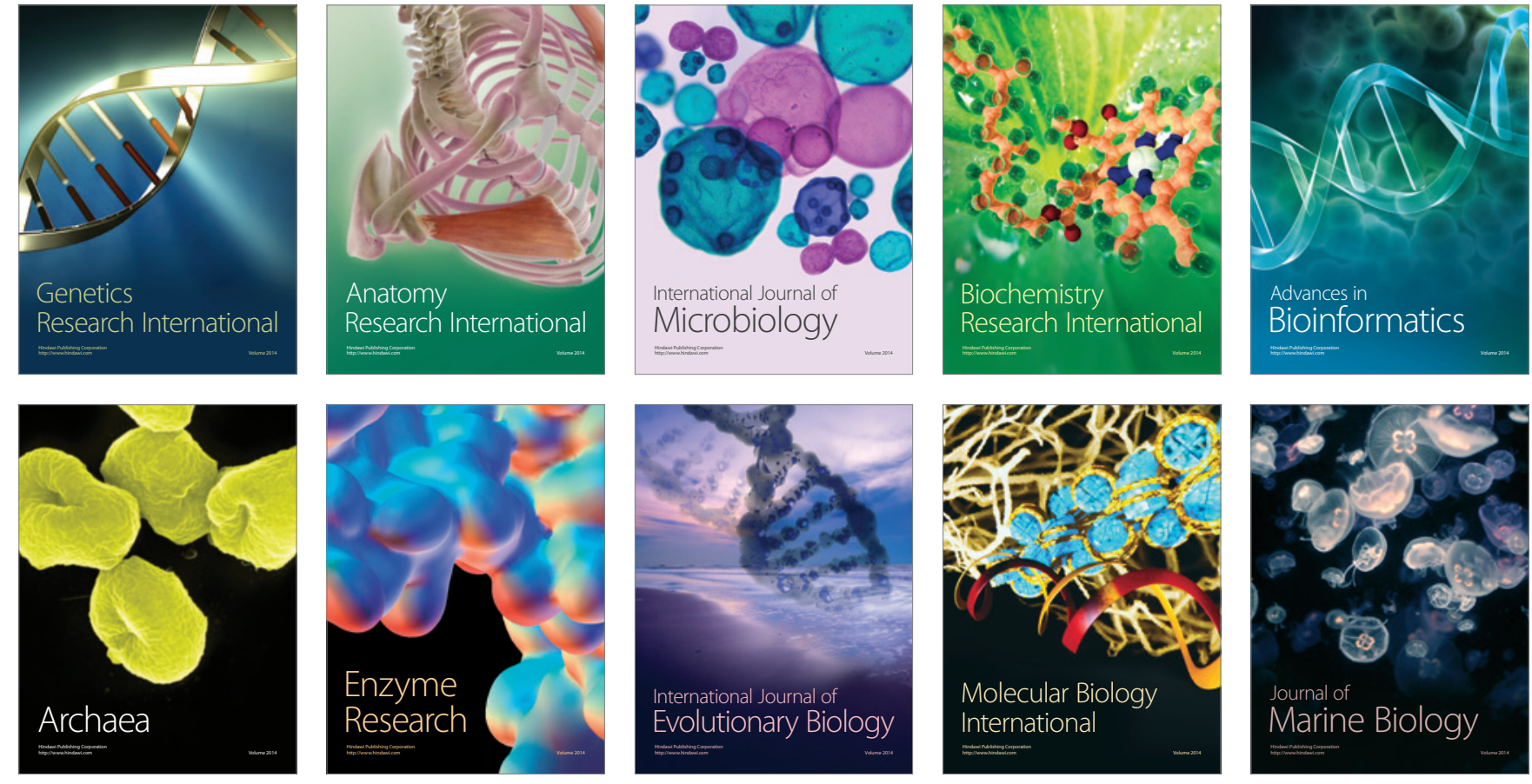